\title{
The African Sate Neo-patrimonial Governance in a "Democratic" South Africa
}

\author{
Professor Johannes Tsheola \\ Department of Development Planning \& Management, University of Limpopo \\ P.O. Box 313, Fauna Park, 0787 \\ johannes.tsheola@ul.ac.za
}

Doi:10.5901/mjss.2014.v5n20p947

\begin{abstract}
Policy studies demonstrate that reality is complex and is rarely matched by statements of intent. Inevitably, governance of a democratic political system necessarily involves a degree of incoherence. Rather than pioneer a new distinct epoch of African governance, the African National Congress-led (ANC-led) state merely legitimized continuities of Africa's extraversion and transposition of the Westphalian state model. With regard to its continental reach, the ANC-led nation-state has appeared to emulate an "Empire", a global capitalist neo-patrimonial state, which was simultaneously reconstituted at a global scale and ruled by proxy through the multilateral organs such as the International Monetary Fund, World Trade Organization and the World Bank. These externalities, together with other ratings as one of the most corrupt states in the world, underscore the ANC-led democratic state's failure to provide a dependable model of governance and state restructuring in Africa. Twenty years on, it has to be asked if the ANC-led state merely delivers the 54th failed state, reinforcing cultural determinism stereotypes of successive cohorts of African leaders being incapable of "good" governance? This article argues that the ANCled democratic state too, has quickly deteriorated into a neo-patrimonial state. Just like in most of Africa, the state has increasingly being weakened whilst the governing regimes were made relatively stable, sometimes stronger. It concludes that increasingly the ANC-led neo-patrimonial state incorporates elements of personalized rule, elite subservience to the core and a shadow state, where differentiation between the public and private spheres of governance is disappearing.
\end{abstract}

Keywords: Governance; Neo-patrimonialism; African State; African National Congress; South Africa

\section{Introduction}

The truism of contemporary global governance of economics and politics is eloquently expressed in Glemarec and Puppim de Oliveira's (2012, p.207) citation of the late economist Kenneth Boulding that public administrations make policy tools and instruments that shape functionaries, rather than the converse. Globally, hegemonic public discourse and state practice relating to development trajectories and strategies for meeting the challenges of sustainable development, whilst reducing poverty and inequality, are captivated by four main development paradigms, which Glemarec and Puppim de Oliveira (2012, p.200) describe as "growth-focused", "pro-poor growth", "green-growth" and "resilient growth". Whereas these development paradigms, and corresponding strategies, offer in isolation insufficient responses to the challenges of reducing societal poverty and inequality (Glemarec and Puppim de Oliveira, 2012), contemporary public administration has reinvented the market-state paralysis (Tsheola, 2013). In most of Africa, though, the market-state paralysis appears to be intricately embedded with the failure of governance and neo-patrimonialism (Berman, 1998; Clapham, 2001; Albert, 2005; von Soest, 2006; Pitcher, Moran and Johnston, 2009). According to Glemarec and Puppim de Oliveira (2012, pp.200-201), the "massive market and governance failures ... persistently ignored by economic and development strategies", are public administration omissions. Hence, Clapham (2002) characterizes contemporary territorial divisions of the geography of the globe into sovereign states as a recent development and product of European colonialism, paradoxically normalized through decolonization and embedded with coloniality of knowledge, being and power (Grosfoguel, 2007; Maldonado-Torres, 2007; Gordon, 2011; Ndlovu-Gatsheni, 2013). To this extent, the modern state is construed as an "expensive organization to maintain" in both economic terms and its demand on the publics, especially through its burdensome nature on the poor citizenry (Clapham, 2002, p.775). The unfettered reverence and adherence to the capitalist economic relations is a naïve ignorance of the suboptimal experiences of the global South, perpetuated through coloniality of knowledge, being and power (Grosfoguel, 2007; Maldonado-Torres, 2007; Gordon, 2011; Mkandawire, 2011; Ndlovu-Gatsheni, 2013). Apparently, contemporary meta-narratives of globality serve to differentially privilege and denigrate forms of knowledge, being and power (Mkandawire, 2011).

The notion of coloniality describes "long-standing patterns of power that emerged as a result of colonialism, but 
that define culture, labour, intersubjective relations, and knowledge production well beyond the strict limits of colonial administrations" that have manifested in spatio-temporal matrices of power, knowledge and being with contemporary globality of capitalism (Maldonado-Torres, 2007, p.243). Unavoidably, coloniality has become elusive because,

"it is maintained alive in books, in the criteria for academic performance, in cultural patterns, in common sense, in the self-image of peoples, in aspirations of self, and so many other aspects of our modern experience. In a way, as modern subjects, we breath coloniality all the time and everyday" (Maldonado-Torres, 2007, p.243).

Importantly, this phenomenon reflexively recreates and sustains itself "through a combination of violence, deceit, hypocrisy and lies" (Ndlovu-Gatsheni, 2013, p.11). Unsurprisingly, characterizations of contemporary African states and elites has continued to be contestable ranging from those that describe them as "venal", "prebendal", "overdeveloped", "dependent", "rentier", "vampire", "petty bourgeois", "neo-colonial", "neo-patrimonial" to the "gatekeepers" (Mkandawire, 2011, p.21). In South Africa, whose constitutional democracy is globally celebrated, state elites are openly accused of "crony capitalism and tenderpreneurship" (Desai, Maharaj and Bond, 2011). Whereas Pitcher, Moran and Johnston's (2009, p.125-156) rejection of the conceptualization of "patrimonialism and neo-patrimonialism as negative regime types associated with corruption, clientelism, and autocracy" cannot be ignored, the pervasive personalistic (patrimonial) logic of stronger regimes and weaker states amidst distortion and personalization of state power, corruption of authority and bureaucratic personal aggrandizement remain theoretically unaccounted in Africa. This article adopts the conception of neo-patrimonialism to characterize the personalistic logic that pervades African states, regimes and elites, without hoping to claim continental or South African "exceptionalism". Indeed, the article does not seek to insinuate that corruption, clientelism and autocracy are inevitable outcomes of personalistic logic.

\section{The Neo-Patrimonial Logic and African Governance: Unresolved Discourse?}

Pitcher et al. (2009) argue that contemporary conceptions of neo-patrimonialism as a pervasive negative regime for governance of Africa associated with corruption, clientelism and autocracy are a product of the misreading of Weber's patrimonialism. Overwhelmingly, scholarly explanations of African governance through the concept of patrimonialism have, according to Pitcher et al. (2009, p.127), insisted that personalistic power and rule have remained the primary obstacles for continental progress "even in the face of democratization and bureaucratic reforms". Using the Botswana model, Pitcher et al. (2009) cast as simplistic, the notion that personalistic power and rule has historically led to dysfunctional democracies and citizenry activism, because patrimonialism has become "a convenient catch-all for Africa's ills". Whereas this caution and call for "rethinking patrimonialism and neo-patrimonialism in Africa" is reasonable, its rationale is unfortunately constructed on the misconception of the deep fissures between tenets and practices of traditional society and modern democratic governance in the continent. Globally, liberal democracies too have faced selfselection between merit and patronage system or merit and representativity in governance of economics and politics (Labuschagne 2010; Chikane 2012). The African traditional system of governance, even where tempered with aspects of modern globalist logic, does not invalidate the notion of a strong association between neo-patrimonialism and social ills such as corruption, patronage, dearth of accountability, abuse of state power, state violence and nepotism in Africa. Pervasiveness of patrimonial logic everywhere in African states "favours well-connected insiders over innovative outsiders", to use The Economist (2012, p.11) conceptual coinage. Prevalence of African patrimonial logic is intricately associate with states "plagued by cronyism and corruption", if Wooldridge's $(2012$, p.4) phraseology could be borrowed. Russian and Egyptian experiences affirm that "bureaugarch" regimes attendant to the scramble for state rule and power under pervasive patrimonial logic tend to dominate both the state and business, thereby (re)producing "cronyism, inequality and eventually discontent" (The Economist, 2012, p.11).

Clapham (2002, p.775) asserts that "while individual cases of state failure and collapse may owe much to specific circumstances and the behavior of particular individuals, they must also be understood within the context of a world in which maintaining states has become increasingly difficult". African states have appeared to be "expensive" to maintain in the contemporary international system largely because the global public discourse is itself captivated by the four fragmentary and poorly integrated development paradigms, where none holds "a monopoly on innovation, social justice, resource efficiency or pro-active risk management" (Glemarec and Puppim de Oliveira, 2012, p.206). Hence, there is "hollowness" in the "existing models of sovereign states" and the global statehood "narratives of security, representation, and wealth and welfare" (Clapham, 2002, p.775). That is, coloniality of knowledge, power and being has continued to be pervasive for Africa, necessitating therefore rigorous examinations of the concept of neo-patrimonial governance in South Africa itself, a liberal democracy. South Africa's governance has always held promise, but the past twenty years of democracy has been clouted with discrepancies in implementation. By definition, poor governance is an antithesis of "good governance", characterized therefore by corruption, clientelism, autocracy, dearth of accountability and 
unresponsiveness to the genuine needs and aspirations of society. Undoubtedly, the culture of corruption, selfenrichment and conspicuous consumption among a few state functionaries and poor responsiveness to citizens' popular grievances, often visited with brutal state violence, has become endemic in the past twenty years (Ballard, Habib and Valodia, 2006; Buhlungu and Atkinson, 2007; Atkinson, 2007; Southall, 2007; Binza, 2010; Thornhill, 2010; Desai, Maharaj and Bond, 2011). Given that the ruling party, the African National Congress (ANC), is a former mass-based liberation movement, genuine questions of state neo-patrimonialism should be framed. Post-2000, state and party power were deliberately centralized (Atkinson, 2007; Binza, 2010); and, it can germanely be construed that the ANC, likely to continue its hold of state power for the foreseeable future as "the natural party of government" (Butler, 2007, p.35), could equally agitate for pervasive patrimonial logic. It will be hard to dismiss the reality that the ruling regime has increasingly become stronger whilst the state weakened.

Importantly, Pitcher et al. (2009) neglect the wide gap in capabilities between African traditional authorities and the modern democratic polities. Thus, modern democratic governance, agitated through the globalist logic, do not espouse values and customs similar to those of African traditional authorities. In South Africa itself, the structuring of relations between the Zulu King and subjects as well as the modern democratic state have remained perpetually in negative national headlines. It is for the same reasons that the Swaziland system is abhorred from the modern globalist logic. For these reasons, this article holds that personalistic power and rule continued to operate optimally under African traditional societies and authorities, but that such pervasive patrimonial logic exclusively holds deleterious effects of non-responsive regimes, state violence, autocracy, lack of accountability, corruption, nepotism, clientelism and such other social ills, under modern democratic electoral governance. That is, the rejection of the interpretive value of the concepts of patrimonialism and neo-patrimonialism in African governance is a dangerously flawed call for continued adherence to the modern globalist logic of fundamentalist universality and truths. Botswana's governance model is a far cry from a typical African regime, elite and state. Instead, African governance yawns for pluriversal epistemic perspectives. Inescapably, contemporary Africa and South Africa cannot be tenably described as post-colonial and post-apartheid, respectively, largely because the "colonial axis" continues to be persistently inscribed in relations of domination, exploitation and "the production of subjectivities and knowledge" (Grosfoguel, 2007, p.221). Such coloniality will continue to produce and reproduce subaltern African governance under modern globalist logic democratic bureaucracies if they are pervaded by patrimonial logic.

Indeed, Africa's neo-patrimonial states incorporate elements of "personalized rule", "elite subservience to the core" and "a shadow state", where there is no differentiation between the public and private spheres of governance (Chabal and Daloz, 1999; Herbst, 2000; Boas, 2003; Fawcett, 2005; Cammack, 2007; Bayart, 2009; Gibb, 2009). Governance tends to be focused on "personal power, patronage, clientelism and, from a Western perspective, corruption" (Gibb, 2009, p.716). Under neo-patrimonial governance, the state control of resources and power is made to reside at the heart of African regimes' reluctance to share sovereignty for collective development (Chabal and Daloz, 1999; Herbst, 2000; Boas, 2003; Fawcett, 2005; Bayart, 2009; Gibb, 2009). The same predicament occurs in domestic politics where the citizenry's needs are circumvented as the regimes become increasingly autocratic, unresponsive, despotic and violent. Under such governance and regimes, "development, is less important to the neo-patrimonial state elites than the continuation of their personal power and prestige"; and, the imperative for promotion and enhancement of the "orderinducing properties" even under reformed bureaucratic democracies inspired by the modern globalist state logic (Fawcett, 2005, p.21; Gibb, 2009, p.716).

A regionalism perspective provides conclusive logic of the deleterious effects associated with personalistic rule and power in Africa. African leaders have historically supported "tangible plans" for "achieving unity and development" and continental recovery and renewal (Ramutsindela, 2009, p.2). In practice, though, African states seem to have been unwilling to share sovereignty, a quality assumed to be necessary for the success of continental initiatives (Gibb, 2009; Bachmann and Sidaway, 2010). For instance, most African states ceded membership to instruments of continental governance such as the Peer Review Mechanism for the purposes of "mobilizing resources and asserting state sovereignty" (Bachmann and Sidaway, 2010, p.1). Both Gibb (2009, p.718) and Bachmann and Sidaway (2010, p.4) attest to the notion that African states have instead adopted an approach that is "actually rather more nuanced and sophisticated, designed principally to support the neo-patrimonial African state system". Evidently, the scope for the socalled post-colonial exercise of state sovereignty has been intricately intertwined with regionalism and/or continentalism, thereby allowing for the establishment of nominal regional/continental cohesion plans, and rhetorical commitments and configuration of sovereignty (Bachmann and Sidaway, 2010). Given the myriad of regional integrative initiatives in Africa, the question of a long history of continental failure to establish blocs that are significant on the global stage cannot be divorced from neo-patrimonial rule and power demonstrated by President Mugabe of Zimbabwe against the African Union $(A U)$. South Africa's ceding of membership of the BRICS amidst dysfunctional African regional blocs and the evaporation 
of the continental economic community vision cannot be dissociated from this country's twenty years of faded "civilizing" missions under the rubric of African Renaissance. At the national scale, recent popular uprisings against African regimes are indicative of the pervasiveness of personalized rule, powerfulness of "strong men" and "weak states". In fact, Pitcher et al. (2009, p.149) paradoxically conclude that "Many contemporary African leaders and the bureaucrats who serve them have consciously distorted history to justify dictatorial rule on national and local levels". At the core of this struggle is the scramble for unfettered personalized state rule and power which, ironically, entails public legitimization.

Sidaway (1998) establishes that regionalism and/or continentalism plans tend to inscribe state powers wherein the state elite exercises and reasserts sovereignty. Dismissing the notion of concessions of state sovereignty and power, Sidaway (1998, p.571) views Africa's regionalism and continentalism plans, therefore, as a "set of processes by which sovereignty is confirmed", because, as Bachmann and Sidaway (2010, p.4) observe, they operate as "a way to demonstrate and bolster sovereignty through participating in practices only open to state actors". Various conceptions of regionalism and/or continentalism for development, such as that by former President Thabo Mbeki's leadership of African Renaissance and the New Partnership for Africa's Development (NEPAD), have to be understood in this context. With the exception of Morocco, which did not cede membership of the AU due to the inclusion of South West Sahara, all other African states joined; however, a majority of them have not committed to subjecting themselves to the Peer Review Mechanism. According to Ramutsindela (2010, p.93), African states have historically sought to use the idea of regionalism and/or continentalism as a strategy for securing sovereignty and fund-raising.

From the neo-patrimonial perspective, therefore, regionalism and/or continentalism plans presuppose a sense of virility of African state sovereignty and regime legitimacy, on the erroneous assumption that it encapsulates state interests (Sidaway, 2002; Fawcett, 2005; Gibb, 2009; Ramutsindela, 2009; Mkandawire, 2011). African states have willy-nilly sought for regional and/or continental arrangements in order to bolster "the image of state sovereignty" and regime legitimacy (Sidaway and Gibb, 1998; Sidaway, 2002; Fawcett, 2005; Gibb, 2009; Ramutsindela, 2009; Mkandawire, 2011). The resultant nominal regionalism and continentalism provides a useful form of "non-threatening" legitimacy without imposing the requirements for germane democracy, genuine sharing of sovereignty and/or development (Sidaway and Gibb, 1998; Sidaway, 2002; Boas, 2003; Fawcett, 2005; Gibb, 2009; Ramutsindela, 2009; Mkandawire, 2011). Such personalized state rule and power cannot deliver forms of governance through legitimate domination or authority, contrary to Pitcher et al.'s (2009) insinuation, in Africa's modern globalist democratic logic. Prevalence of patrimonial logic with personalized rule and power cannot find any legitimacy for domination or authority under any form of modern globalist democracy. Inevitably, the scramble for patrimonial logic in African states will be inextricably interwoven with the ruling regimes' desire to legitimize patronage, cleintelism, corruption and such other self-interested social ills. The unwarranted recall of former President Mbeki from Office in 2008, following his installation of personalized state rule through the modernization project (Chikane, 2012), is tangible evidence of the increasing pervasiveness of a nuance regime of neopatrimonial logic, specific to a democratic South Africa. The ruling party has now conceded that it has become increasingly difficult to uproot the culture of corruption and cronyism in a democratic South Africa (Binza, 2010; Ballard et al. 2006; Southall 2007; Thornhill 2010).

\section{Post-2000 ANC-led South African State in Africa: "Exceptionalism" or Neo-patrimonial Governance}

The question that remains mythical is whether there is any post-colonial and post-apartheid polity in Africa and South Africa, respectively? By itself, this question insinuates that South Africa's claim of "exceptionalism" is false; hence, attempts at continental "civilizing" missions through the African Renaissance under former President Mbeki have waned in frustration as most of Africa overtly resisted this country's "big brother" mentality. Then, the ANC-led state sought to establish itself as a "credible champion of human rights, democracy and good governance by promoting respect for humane values and practices" (Landsberg, 2000, p.80). Hence, the New Partnership for Africa's Development (NEPAD) which was championed by former President Mbeki holds deep reverence for these principles. As Gibb (2009, p.714) argues, neo-patrimonial logic in African states, regimes and elites has vividly illustrated that state interests are not "national self-interests". In this context, former President Mbeki's state and party power centralizing modernization project cannot be assumed to have been in South Africa's national self-interest.

Post-2000, South Africa came to be increasingly confronted with the public market and private market dilemmas of balancing "efficiency and equity (who gets what and where) objectives" (Smith, 2004, p.375); simultaneously, there was increasing acceptance that markets "can play a unique role in allocating scarce resources efficiently" without driving substantial transformation for social justice in deeply unequal societies (Glemarec and Puppim de Oliveira, 2012, p.200). A democratic South Africa is such a society where the national political-economy was ironically captivated by efficiency, above political equity, considerations (Bond, 2004; Smith, 2004; Jaglin, 2008; Tshandu, 2010). The resultant public 
discourse became deeply fragmentary, necessitating the scramble for state rule and power, which became both economic and political prize (Desai et al., 2011; Biko, 2013; Calland, 2013; Habib, 2013). On its part, the ruling ANC quickly degenerated into a "catch-all, bread and butter" electoral party concentrating on competence and size above ideology (Butler, 2007; Southall, 2007). Such conduct of governance by a ruling party that is assured of winning national elections in the foreseeable future is inescapably embedded with increasing pervasiveness of neo-patrimonial logic (Pitcher et al., 2012), especially under circumstances where South Africa is regarded as the corruption capital of the world.

During former President Mbeki's term as ANC president, attempts were made to impose strict instrumental order in the ANC (Ballard et al. 2006; Butler 2007; Southall 2007; Mason 2009; Mbeki, 2009; Biko, 2013; Calland, 2013; Habib, 2013). Former President Mbeki's modernization project encouraged personalized rule, exercise of unaccountable power and dearth of responsiveness to the citizenry's legitimate needs, whilst party succession battles degenerated into economic and political prize (Butler 2007, p.44). Centralization of power did happen within the ANC wherein Luthuli House exercised virtual instrumental control over factionalism and regionalism, neutralized politics and regulated careerism, moves which thwarted scope for political debate, instead intensifying party hierarchy patronage (Lodge 2004; Buhlungu and Atkinson 2007; Butler 2007; Ballard et al. 2006; Orkin and Jowell 2006; Southall 2007; Mason 2009; Mbeki 2009; Hammett 2010; Chikane 2012).

Far from the loud public stunts, the ANC has through its self-selection of public administration demonstrated deep reverence for patronage and political manipulation (Mason 2009; Binza 2010; Brynard 2010; Labuschagne 2010; Thornhill 2010; Chikane 2012). The ANC leadership has accepted that political connections, as business and economic prize, reign supreme over principles of "impartiality, fairness, public accountability, transparency, empowerment and effective use of resources" (Southall 2007, p.11). The evident contestations for party and state power among the ANC functionaries as well the unflinching application of state apparatus to settle such scores conclusively point to the prevalence of a neo-patrimonial logic wherein the "weak state" is governed by "strong man" regimes. According to Boas (2003, p.33), "the neo-patrimonial post-colonial state has created a state that is both strong and weak simultaneously"; as a result, there exist "remarkably stable regimes" governing weak states in Africa. Hence, questions of whether the ANC ruling elite would win subsequent national elections should be firmly planted on ice for the foreseeable future. The seemingly enduring case of President Robert Mugabe's regime in Zimbabwe presents an interesting example in this regard. The recall of former President Mbeki a few months before his final term as president and the unending squabbles in the ruling party, following the presidential succession contestations in Mangaung in December 2012, do not inspire nuances form of regime legitimacy or authority for non-patrimonial governance.

Like in most of the so-called post-independent African states, the ANC-led state has increasingly being weakened whilst the governing regimes have become relatively stronger. Evidently, the ANC-led neo-patrimonial state incorporates elements of "personalized rule", "elite subservience to the core" and "a shadow state", where differentiation between the public and private spheres of governance has systematically waned. It is an unpalatable truth that contemporary South Africa's state governance has focused on personal power, patronage, clientelism and, perhaps, corruption. National politics are firmly captivated by state control of resources and power of the governing regimes, and the ruling elites' apparent reluctance to uphold civic virtues, democratic principles and ideals. Rather than focus on "order-inducing properties" of a democratic state, the ANC governing regimes have in recent times struggled for control over the neopatrimonial state and the rampant pursuit of "personal power and prestige". In practice, the ANC-led neo-patrimonial state has created a sense of virility of regime legitimacy and state sovereignty, both nationally and internationally, in order to bolster engagement of "nominal and non-threatening democracy".

\section{Conclusion}

This article has argued that neo-patrimonialism continues to provide an adequate conceptual tool for analyzing and understanding the occurrence of social ills of corruption, state violence, autocracy and dearth of accountability that are intricately associated with personalistic state rule and power. It rejects the suggestion that an African traditional governance system is adequate for dismissal of the conceptions of patrimonialism and neo-patrimonialism. Indeed, the article concedes that neo-patrimonialism cannot be a catch-all concept for the explanation of all of Africa's governance ills. However, it strongly asserts that patrimonial states, regimes and elites make for deleterious consequences of blurring private with the public as well as deconstruction of state power as economic and political prize. The article points to manifestations of neo-patrimonialism of a special form in South Africa's ANC ruling regimes and elites. It concludes that the characterization of contemporary South Africa as the global capital of corruption, amidst incessant contestations of party and state power, following former President Mbeki's centralization modernization project, must render the 
conception of neo-patrimonialism specifically pertinent for this polity.

\section{References}

Albert, I.O. 2005. Explaining 'godfatherism' in Nigerian politics. African Sociological Review, 9(2), 79-105.

Atkinson, D. 2007. Taking to the streets: has developmental local government failed in South Africa. In S. Buhlungu, J. Daniel, R. Southall and J. Lutchman (eds.), State of the Nation: South Africa 2007, pp. 53-77. HSRC, Pretoria.

Bachmann, V. and Sidaway, J.D. 2010. African regional integration and European involvement: external agents in the East African Community. South African Geographical Journal, 92(1), 1-6.

Ballard, R., Habib, A. and Valodia, I. (eds.). 2006. Voices of Protest: Social Movements in Post-apartheid South Africa. University of KwaZulu-Natal Press, Scottville.

Bayart, J-F. 2009. The State in Africa: the Politics of the Belly (2nd ed.). Polity Press, Cambridge.

Berman, B.J. 1998. Ethnicity, patronage and the African state: the politics of uncivil nationalism. African Affairs, 97, 305-341.

Biko, H. 2013. The Great African Society: A Plan for a Nation Gone Astray. Jonathan Ball Publishers, Johannesburg.

Binza, M.S. 2010. Developmental local government in the $21^{\text {st }}$ century: implementing local economic development as a new mandate. Administratio Publica, 18(4), 241-260.

Boas, M. 2003. Weak states, strong regimes: towards a "real" political economy of African regionalisation. In J.A. Grant and F. Soderbaum (eds.), The New Regionalism in Africa. Ashgate, Aldershot.

Bond, P. 2004. Talk Left, Walk Right: South Africa's Frustrated Global Reforms. University of KwaZulu-Natal Press, Scottsville.

Brynard, D.J. 2010. The duty to act fairly: A flexible approach to procedural fairness in public administration. Administratio Publica, 18(4), 124-140.

Buhlungu, S. and Atkinson, D. 2007. Politics: introduction. In S. Buhlungu, J. Daniel, R. Southall and J. Lutchman (eds.), State of the Nation: South Africa 2007, pp. 27-34. HSRC, Pretoria.

Butler, A. 2007. The state of the African National Congress. In S. Buhlungu, J. Daniel, R. Southall and J. Lutchman, J. (eds.), State of the Nation: South Africa 2007, pp. 35-52. HSRC, Pretoria.

Calland, R. 2013. The Zuma Years: South Africa's Changing Face of Power. Zebra Press, Cape Town.

Chabal, P. and Daloz, J. 1999. Africa Works: Disorder as Political Instrument. James Currey, London.

Chikane, F. 2012. Eight Days in September: the Removal of Thabo Mbeki. Picador Africa, Johannesburg.

Clapham, C. 2001. Rethinking African state. African Security Review, 10(3), 6-16.

Clapham, C. 2002. The challenge to the state in a globalized world. Development and Change, 33(5), 775-795.

Desai, A., Maharaj, B. and Bond, P. 2011. Introduction: Poverty eradication as Holy Grail. In B. Maharaj, A. Desai and P. Bond (eds.), Zuma's Own Goal: Losing South Africa's 'War on Poverty, pp.1-35, Africa World Press, Inc., Trenton.

Fawcett, L. 2005. Regionalism from a historical perspective. In M. Farrell, B. Hettne and L. van Langenhove (eds.), Global Politics of Regionalism: Theory and Practice. Pluto Press, London.

Gibb, R. 2009. Regional integration and Africa's development trajectory: meta-theories, expectations and reality. Third World Quarterly, 30(4), 701-721.

Glemarec, Y. and Puppim de Oliveira, J.A. 2012. The role of the visible hand of public institutions in creating a sustainable future. Public Administration and Development, 32, 200-214.

Grosfoguel, R. 2007. The epistemic decolonial turn. Cultural Studies, 21(2-3), 211-223.

Habib A 2013. South Africa's Suspended Revolution: Hopes and Prospects. Johannesburg: Wits University Press.

Hammett, D. 2010. Zapiro and Zuma: a symptom of an emerging constitutional crisis in South Africa? Political Geography, 29, 88-96.

Herbst, J. 2000. States and Power in Africa: Comparative Lessons in Authority and Control. Princeton University Press, Princeton.

Jaglin, S. 2008. Differentiating networked services in Cape Town: echoes of splintering urbanism? Geoforum, 39, 1897-1906.

Labuschagne, P. 2010. Local government and service delivery in South Africa: an investigation into the defence of necessity. Administratio Publica, 18(4), 93-107.

Landsberg, C. 2000. Mbeki's external initiative on Africa and the global South. Africa Insight, 30(3), 75-81.

Maldonado-Torres, N. 2007. On the coloniality of being. Cultural Studies, 21(2-3), 240-270.

Mbeki, M. 2009. Architects of Poverty: Why African Capitalism Needs Changing? Picador Africa, Johannesburg.

Mkandawire, T. 2011. Running while others walk: knowledge and the challenge of Africa's development. Africa Development, 36(2), 136.

Ndlovu-Gatsheni, S.J. 2013. Why decoloniality in the 21st century? The Thinkers, 48, 10-15.

Pitcher, A., Moran, M.H. and Johnston, M. 2009. Rethinking patrimonialism and neopatrimonialism in Africa. African Studies Review, 52(1), 125-156.

Ramutsindela, M. 2009. Gaddafi, continentalism and sovereignty in Africa. South African Geographical Journal, 91(1), 1-3.

Ramutsindela, M. 2010. Editorial: the SAGJ and 2010. South African geographical Journal, 92(2), 91-95.

Sidaway, J.D. 1998. The (geo)politics of regional integration: the example of the Southern African Development Community? Environment and Planning D: Society and Space, 16, 549-576.

Sidaway, J.D. 2002. Imagined Regional Communities: Integration and Sovereignty in the Global South. Routledge, London.

Sidaway, J.D. and Gibb, R. 1998. SADC, COMESA and SACU: contradictory formats for regional integration in southern Africa. In D. Simon (ed.), South Africa in Southern Africa: Reconfiguring the Region. James Currey, London. 
Smith, L. 2004. The murky waters of the second wave of neoliberalism: corporatization as a service delivery model in Cape Town. Geoforum, 35, 375-393.

The Economist, 2012. The rise of state capitalism: the emerging world's new model. 402(8768), 11-12.

Tshandu, Z. 2010. Service plans as accountability mechanisms: evidence from the South African public service. Administratio Publica, 18(4), 46-70.

Tsheola J. 2013. State capitalism meta-governance, state-capital nexus and state activism paradoxes in the Gauteng freeways. Journal of Public Administration, 48(1), 35-50.

Von Soest, C. 2006. How does neopatrimonialism affect the African state? The case of tax collection in Zambia. German Institute of Global and Area Studies (GIGA) Working Papers No. 32, GIGA Research Programme Unit 'Legitimacy and efficiency of Political Systems', Hamburg.

Wooldridge, A. 2012. State capitalism: the visible hand. The Economist, 402(8768), 1-18. 